\title{
Insecticidal activities of indigenous plants from Volta Region, Ghana in managing Sitophilus zeamais and Prostephanus truncatus in stored maize
}

\author{
DAVID KODJO ANKUTSE ${ }^{1}$, VINCENT YAO EZIAH ${ }^{1}$, KWAME AFREH-NUAMAH ${ }^{1, \bullet}$ \\ Department of Crop Science, University of Ghana. MR28+334, Accra, Ghana. Tel.: +233-506-656813, `email: knuamah@ug.edu.gh
}

Manuscript received: 5 December 2021. Revision accepted: 24 October 2021.

\begin{abstract}
Ankutse DK, Eziah VY, Afreh-Nuamah K. 2021. Insecticidal activities of indigenous plants from Volta Region, Ghana in managing Sitophilus zeamais and Prostephanus truncatus in stored maize. Intl J Trop Drylands 5: 48-60. The rising rate of pest resistance, and the high expense and health risks associated with insecticide use, have become a source of public concern. This study aimed to discover and evaluate plant species used by farmers in the Volta Region to control Sitophilus zeamais (Motschulsky, 1855) and Prostephanus truncatus (Horn, 1878) in stored maize grains. In a survey, Azadirachta indica, Clausena anisata, Phyllanthus amarus, Picralima nitida, Vernonia amygdalina, Nauclea latifolia, and Momordica charantia were discovered to be grain protectants against stored insect pests. All of the plants indicated above were employed in the experiment, except for A. indica, which has a long history of being used to combat grain storage pests. The insecticidal activity of dried powders (5 and 10\%) and aqueous extracts $(0.1$ and 0.2 $\mathrm{g} / \mathrm{mL}$ ) of plants against $P$. truncatus and $S$. zeamais was examined. Plant species and dose rate influenced repellency. In the $V$. amygdalina treatment, plant powders and methanol extracts were the most poisonous to insects. The toxicity of $V$. amygdalina to $P$. truncatus and S. zeamais was 83.3 and $86.7 \%$, respectively, at higher concentrations of $0.2 \mathrm{~g} / \mathrm{mL}$. At $0.2 \mathrm{~g} / \mathrm{mL}$, all plant extracts exhibited a significant difference in Actellic repellent (P0.05); nevertheless, $C$. anisata had the highest repellent action against $P$. truncatus and S. zeamais, with 80.0 and $66.7 \%$, respectively. As grains were treated with plant extracts, oviposition and egg emergence were reduced compared to the control. When embryonic stages of insects were treated with methanol extracts of botanicals, the number of adult insects decreased. These findings show that the studied plants have the potential to aid in the development of post-harvest protection technology against the principal pests of stored grains, P. truncatus and S. zeamais. As a result, farmers should use it to control P. truncatus and S. zeamais in stored maize grains.
\end{abstract}

Keywords: Indigenous plants, insecticidal, Prostephanus truncatus, Sitophilus zeamais, Zea mays

\section{INTRODUCTION}

Maize (Zea mays L.) is a member of the Gramineae family and is one of the most significant cereal crops grown in various agro-ecological environments around the world (Owusu-Sekyere et al. 2011). Maize is produced in greater quantities than any other grains, and statistics reveal that maize accounts for $37 \%$ of total cereal consumption in Sub-Saharan Africa (Quandzie 2011). In Ghana, it is grown in all ten regions of the country with the Eastern Region being the most prolific producer. Maize is only third in production after roots \& tubers and plantain (MOFA 2008). Maize farming takes up less space than wheat or rice, but produces a higher average output per unit area of roughly 5.5 tons per hectare (Obeng-Ofori and Dankwah 2004).

Maize is used for three main purposes: human food, industrial raw materials, and livestock feed. According to IITA (2003), globally, 66\% of all maize is utilized for livestock feed, $25 \%$ for human consumption, and $9 \%$ for industrial purposes. However, in poor countries such as Ghana, around half of all maize is consumed as food, while the remaining $43 \%$ is given to livestock and the rest is used for industrial purposes. Whole grains are either mature or immature (fresh corn) or various processed forms, depending on the location or ethnic group. It can also be processed into a wide range of intermediate goods, including different-sized maize grits, maize meal, maize flour, and flaking grits.

Despite maize's importance, storage losses are still relatively substantial. According to FAO (2008), global grain losses amount to about $10 \%$ of all stored grain, i.e., 13 million tons of grain are lost owing to insect pest damage and 100 million tons are lost due to improper storage. According to Cornelius et al. (2008) estimates, losses in developing countries might be as high as $50 \%$ of what is produced. In contrast to perishable crops, maize can be stored for extended periods of time; however, preservation quality during long-term storage is an issue in many regions of the world, as quality decreases with storage duration. Losses in storage might occur as a result of over-drying of grains, weight loss owing to respiration, or the incorrect application of synthetic pesticides. In addition, infestation by rodents and insects, as well as feeding damage, contamination with mycotoxins caused by molds and bacteria, and dead insect parts, can all lead to storage loss (Boxall 2001).

The most common insect pests on maize are Prostephanus truncatus (Horn, 1878) (Coleoptera: Bostrichidae) and Sitophilus zeamais (Motschulsky, 1855) (Coleopteran Curculionidae). The larvae and adults of both 
insects feed on the grain, reducing its viability, quality, and value, as well as its weight and nutrients (Cornelius et al. 2008). Food insecurity and poverty levels among farmers have increased as a result of this predicament, particularly in developing nations like Ghana.

Synthetic pesticides are currently commonly utilized to control insect pests of stored foodstuffs in most developing countries, such as Ghana. However, indiscriminate use of synthetic pesticides has resulted in food poisoning, the extinction of natural enemies and non-target species, pest resistance, the transformation of harmless species into pests, food contamination and air pollution all, of which pose a health risk to humans and animals (Gill and Garg 2014).

As a result, most academics are now focusing on nonchemical grain storage systems in order to limit the usage of synthetic insecticides. Plants have significant economic and health benefits for users, consumers, and the environment (Elhag 2000; Talukder and Howse 2000). The usage of plant extracts has a variety of impacts on insects. They are non-toxic to warm-blooded animals and act as antifeedants, growth regulators, sterilants, oviposition deterrents, repellents, and impair insect fitness (Saxena et al. 1989; Schmutterer 1990). According to Obeng-Ofori (2007), the application of plants as grain protectants from insect damage is gaining traction and yielding favorable results in recent years.

Under these conditions, laboratory and field bioassays were undertaken to determine the efficiency of six indigenous Ghanaian plant powders and extracts against $S$. zeamais and P. truncatus in the Volta Region's Jasikan, Afadjato, and South Dayi Districts. The objectives of this research were (i) To identify the various plant species used to preserve corn in the selected districts. (ii) To determine the antimicrobial efficacy of six potential plant powders against $S$. zeamais and $P$. truncatus in preserved maize. (iii) To determine the toxicity and repellency of the best plant's methanol extract against $S$. zeamais and $P$. truncatus in stored maize. (iv) To determine the optimal concentration of the most effective plant methanol extract against $S$. zeamais and $P$. truncatus in stored maize. (v) To determine the effective concentration of potential plant extract against $S$. zeamais and $P$. truncatus in a bioassay.

\section{MATERIALS AND METHODS}

\section{The study area}

A survey was done in three districts of Ghana's Volta Region (Jasikan, Afadjato, and South Dayi) to ascertain the plants used by farmers to protect maize grains from insect pests. The Jasikan District is one of the Volta Region's twenty-five (25) municipalities and districts. Jasikan serves as the administrative capital. The district is bounded on the east by the Republic of Togo, on the west by the Volta River, on the north by Biakoye District, and on the south by Afadjato District and Kpandu Municipal. It has an area of $1355 \mathrm{~km}^{2}$ and comprises 33 villages and 33 sub-towns. The primary activity of their inhabitants is farming, with the majority of them being women engaged in small-scale production (Ghanaditricts.com 2013).

In 2012, the Afadjato District was carved out of Hohoe Municipality. Ve-Golokwati serves as the administrative capital of the District. The District is bounded on the north by Hohoe Municipality, on the west by Kpando Municipality, on the east by the Republic of Togo, and on the south by Ho West District and South Dayi District. It comprises around $238,533 \mathrm{~km}^{2}$ and the majority of its inhabitants are peasant farmers who cultivate corn primarily on subsistence scales (ghanaditricts.com 2013).

South Dayi District is located between latitudes 3.020' N and $3.5005 ' \mathrm{~N}$, with longitude $0017^{\prime} \mathrm{E}$. It is bordered on the north by Kpando and Afadjato South, east by Ho West, and south by Asougyaman District, with the Volta Lake forming the western boundary. The District has a total size of $1,000 \mathrm{~km}^{2}$, with the Volta Lake submerging around $20 \%$ of it. The yearly rainfall averages between 900 and 1300 millimeters. The District's vegetation is dominated by Guinea woodland and deciduous forests. The human population of South Dayi District in September 2010 was 46,661, according to the 2010 Population and Housing Census. Farming and fishing activities employ approximately $62 \%$ of the economically active population (Ghanaditricts.com 2013).

The laboratory and final field trials were done at the University of Ghana Farm and the Entomology Laboratory at the Crop Science Department. A ventilated crib of $3 \mathrm{x}$ $1.5 \times 1.5 \mathrm{~m}$ was built with a wooden framework at the University farm of Ghana-Legon. The efficacy of plant extracts against $S$. zeamais and $P$. truncatus in bioassay was determined by storing grains treated with four extracts at two concentration levels in the crib.

\section{Field survey}

The Volta Region's field survey was done in three districts: Jasikan, Afadjato, and South Dayi. Three villages were chosen at random in each district to represent villages, and ten maize farmers in each village were picked with the help of extension officers. Ninety (90) farmers from the three districts were asked open-ended and closed-ended questions. Farmers' demographics, storage methods, maize varieties and effectiveness, and customer acceptability of grain treated with plant extracts were all covered in the questionnaires. The data was examined using the SPSS storage method.

\section{Culturing of insects}

Sitophilus zeamais

Sitophilus zeamais was isolated from contaminated maize grains collected from a maize farmer in the Volta Region's Kpeve. In the Crop Science Laboratory, one hundred adult insects of mixed sexes were infested in $500 \mathrm{~g}$ of sterilized grains in a glass jar covered with muslin cloth. The culture was stored on the laboratory shelf for one week to allow for oviposition. Adult insects were removed, and emerging generations were used to establish the experimental cultures. To get enough insects for the studies, the culturing of $S$. zeamais was repeated four times. 


\section{Prostephanus truncatus}

Prostephanus truncatus samples were collected from infested maize grain stock at Baika in the Jasikan District of the Volta Region and from old stock at the Crop Science Laboratory. First, whole maize grains were sterilized for 3 hours at $60^{\circ} \mathrm{C}$ and then allowed to cool for 12 hours before being utilized in the culture. Then, in a glass jar, one hundred insects of mixed sexes were injected into $500 \mathrm{~g}$ of sterilized maize grains using an aspirator in a controlled room at $28 \pm 2{ }^{\circ} \mathrm{C}$ and $65 \%$ relative humidity (Osafo 1998; Weaver et at. 1998; Udo et al. 2009). Adult insects have sieved away after one week of oviposition and the culture was left to stand for emerging progeny employed to establish the experimental cultures (Udo et al. 2009).

\section{Selection of plants}

The plant species employed in grain storage in this study were chosen based on the following parameters by farmers during a field survey. These considerations include the efficiency of the plant against stored insects, its availability, how frequently it is employed in the area, and whether or not the plant has been utilized or properly researched in the country to store grains.

Seven plants were detected in total (Azadirachta indica, Clausena anisata, Phyllanthus amarus, Picralima nitida, Vernonia amygdalina, Nauclea latifolia, and Momordica charantia), although $A$. indica was not picked due to its considerable research in the country. The synthetic reference pesticide Actellic was chosen since it is one of Ghana's most frequently utilized synthetic chemicals for grain storage. The names of the plants, their local names in the location where they were collected, and the portions used to prepare the plant powders and extracts are listed in Table 1.

\section{Preparation of plant powders}

The components of the six plant species were gathered from Baika in the Volta Region's Jasikan District. They were brought to the Crop Science Laboratory of the University of Ghana-Legon, where they were prepared for identification at the university's herbarium in the Botany Department. After washing the plant specimens with tap water to remove sand and other undesirable particles, they were air-dried for 15 days at room temperature. Next, the specimens of the chosen plants were beaten using a mortar and pestle before being processed into a fine powder. To achieve homogeneous size particles, the powders were sieved with an Impact Test Sieve with a mesh size of 70. A day before being employed for grain treatment, the crushed powders were kept in six distinct airtight containers.

\section{Preparation of methanol extract of plants}

Six conical flasks containing $430 \mathrm{~mL}$ each of $100 \%$ methanol were filled with approximately $100 \mathrm{~g}$ of the plant powders. For 48 hours, the flasks were covered with Parafilm and shaken. The solution was filtered through a 2.5-mesh filter and concentrated at $60^{\circ} \mathrm{C}$ using a rotary evaporator, following which the residues were dissolved in acetone to obtain concentrations of $0.1 \mathrm{~g} / \mathrm{mL}$ and $0.2 \mathrm{~g} / \mathrm{mL}$ for the various bioassays.

\section{Screening of the six plant powders}

Effect of plant powders on adult insects

Four $\mathrm{kg}$ of whole grains was placed on a metal tray and sterilized in a $60^{\circ} \mathrm{C}$ oven for 3 hours. For 24 hours, the sterilized grains were equilibrated at $28 \pm 2{ }^{\circ} \mathrm{C}$ and $65 \%$ relative humidity in a controlled atmosphere. Sterilized whole maize grains (100 g) were placed in glass jars, and two sets of plant powders (5\% and 10\%) were combined in with the grains. Actellic $25 \mathrm{EC}$ was administered in acetone at a concentration of $2 \mathrm{~mL} / \mathrm{L}$, while the control treatment included no botanical powder. Before introducing 20 adult $S$. zeamais and $P$. truncatus (5-10 days old) into the treated and untreated maize grains, the setups were let to stand for one hour. Under a randomized design, the treatments were replicated four times. For seven days, the daily mortality of insects was recorded. It was declared dead if an insect did not respond to poking with a blunt probe.

\section{Effect of methanol extracts on adult insect in treated grains}

Sterilized maize grains $(50 \mathrm{~g})$ were placed in Kilner glass jars, and four botanicals (C. anisata, $P$. amarus, $P$. nitida, and $V$. amygdalina) were administered to each jar in two concentrations $(0.1 \mathrm{~g} / \mathrm{mL}$ and $0.2 \mathrm{~g} / \mathrm{mL})$. In addition, grain was treated with Actellic $(2 \mathrm{~mL} / \mathrm{L})$ and controltreated with acetone. The treated grains were air-dried for one hour to evaporate the solvent. After introducing twenty adult $S$. zeamais and $P$. truncatus (5-10 days old) into the treated and untreated maize grains, the jars were covered with muslin cloth held in place with rubber bands. The treatments were repeated four times and kept for one week in a controlled chamber at $28 \pm 2{ }^{\circ} \mathrm{C}$ and $65 \%$ relative humidity. Insects were declared dead if they did not respond to three probes with a blunt probe.

Table 1. Plant species used for the experiment

\begin{tabular}{lllll}
\hline Plant species & Local name & Common name & Parts use & Stage of collection \\
\hline Clausena anisata & Ayira & Horsewood & Leaves & Before flowering \\
Phyllanthus amarus & Kpavideme & Phyllantus & Leaves & During flowering \\
Picralima nitida & Quinine & Akuamma plant & Seed & Matured seed \\
Vernonia amygdalina & Gboti & Bitter Leaf & Leaves & Before flowering \\
Nauclea latifolia & Nyimoke & African peach & Root & Maturity \\
Momordica charantia & Kakle & Bitter gourd & Leaves & During flowering \\
\hline
\end{tabular}


Contact toxicity by topical application

The procedure described by Obeng-Ofori and Reichmuth (1997) was used in this test. Ten adults of each $S$. zeamais and $P$. truncatus (5-10 days old) were placed in a separate petri dish lined with damp filter paper for three minutes. Using a micro-pipette, one microlitre of four plant extracts, Actellic, and a control (water) were applied to the dorsal surface of the thorax of insects. The experiment was carried out four times in all. The mortality of insects was measured during five days.

\section{Effect of methanol extracts on oviposition}

$50 \mathrm{~g}$ maize grains were weighed into glass jars and given four different herbal treatments. Another jar was given Actelic at a concentration of $2 \mathrm{~mL} / \mathrm{L}$, whereas the control received no treatment. The treated grains were infested with mixed sexes of 20 adults of $S$. zeamais and $P$. truncatus (5-10 days old) after being left for one hour. To allow for oviposition, the jars were covered with muslin cloth kept in place with rubber bands and put in a controlled atmosphere at $28 \pm 2{ }^{\circ} \mathrm{C}$ and $65 \%$ relative humidity for seven days. The experiment was set up in a completely randomized design with three repetitions. The adult insects were sieved on the eighth day, and the number of eggs laid was calculated using egg plug staining procedures (acid fuchsin method) FAO (2008).

\section{Effect of methanol extracts of plants on eggs and immature stages \\ Effect on eggs}

Six glass jars were filled with sterilized maize grains $(100 \mathrm{~g})$ with a moisture content of $12 \%$. To allow for egg laying, the grains were infested with 20 adult $S$. zeamais and $P$. truncatus (5-10 days old) of mixed sexes in each set of jars. After seven days of oviposition, the adult insects were collected and the percentage of oviposition was calculated before grains were treated with methanol extracts of $C$. anisata, $P$. amarus, $P$. nitida, and $V$. amygdalina at 0.1 $\mathrm{g} / \mathrm{mL}$ and $0.2 \mathrm{~g} / \mathrm{mL}$, respectively. Water and Actellic were used to treat the control and reference groups, and each treatment was repeated three times. In addition, the number of newly emerged adults was counted and recorded.

\section{Toxicity of methanol extracts to larva.}

Twenty adults of $S$. zeamais and P. truncatus (5-10 days old) of mixed sexes were infested with $100 \mathrm{~g}$ of sterilized maize in each glass jar, and oviposition was allowed for seven days. On the seventh day, the adult insects have sieved away, and the grains were permitted to stay for another seven days to allow the eggs to develop into larva. The grains were subsequently treated with two concentrations of plant extracts and Actellic $(0.1 \mathrm{~g} / \mathrm{mL}$ and $0.2 \mathrm{~g} / \mathrm{mL})$, with the control being treated with acetone. Under a completely randomized design, the experiment was repeated four times. The number of newly emerged adults was counted and recorded.

\section{Effect of methanol extracts on the pupa}

In this experiment, $100 \mathrm{~g}$ of sterilized maize grains was placed in twelve glass jars, with twenty adults of $S$. zeamais (5-10 days old) of mixed sexes delivered into six jars and twenty adults of $P$. truncatus introduced into the remaining six jars. On the seventh day following oviposition, the mature insects have sieved. The grains were treated with four different botanical extracts and Actellic at two concentrations $(0.1 \mathrm{~g} / \mathrm{mL}$ and $0.2 \mathrm{~g} / \mathrm{mL})$ on the $22^{\text {nd }}$ day, whereas the control was given water. The emerged adults were numbered and documented after each treatment was reproduced three times in a completely randomized method.

\section{Repellency assay}

The repellency of methanol extracts of plants on $S$. zeamais and $P$. truncatus was determined in the laboratory using Obeng-Ofori and Reichmuth's (1997) approach carried out at $28 \pm 2{ }^{\circ} \mathrm{C}$ and $68-73 \%$ relative humidity. Full disc filter sheets were separated into two halves, with one half being treated with the test solutions $(0.1 \mathrm{~g} / \mathrm{mL}$ and 0.2 $\mathrm{g} / \mathrm{mL}$ ) and the other half being treated with water using a micropipette. The modified filter sheets were air-dried for three hours in the laboratory. The treated and untreated filter papers of the same dimension were joined together to produce a whole disc using sellotape. Each filter paper was placed in a petri dish, and 10 adults (5-10 days old) mixed sexed $S$. zeamais and $P$. truncatus were placed in the center of each filter paper and covered. Three times the experiment was carried out. The number of insects present on the treated $(\mathrm{Nt})$ and control $(\mathrm{Nc})$ groups were counted and recorded 30 minutes after the insects were introduced. $\mathrm{PR}=[(\mathrm{Nc}-\mathrm{Nt}) /[(\mathrm{Nc}+\mathrm{Nt})] \mathrm{X} 100$ was used to calculate the percentage repellency $(\mathrm{PR})$ values.

\section{Damage assessment}

An approach of Cornelius et al. (2008) for assessing grain damage was used. Methanol extracts of four plants treated sterile whole maize grains $(2 \mathrm{~kg})$ each. The control group received simply methanol treatment. The treated grains were then air-dried for three hours before being placed in $30 \times 40 \mathrm{~cm}$ sacks. One hundred $S$. zeamais and $P$. truncatus adults (5-10 days old) of mixed sexes were discharged into two separate bags. Three times each therapy was carried out. The bags were then placed in a crib at the University of Ghana farm for ten weeks, following which the amount of weight lost was calculated using the count and weigh method. 1000 grain samples were taken from each of the treatments, and 500 grains were counted from each sample. Damaged and undamaged grains were isolated from the 500 grains. They were all weighed and counted. The percentage weight loss was calculated using the FAO approach, as updated by Cornelius et al. (2008):

\section{Percent Weight Loss $=(\mathrm{UNd})-(\mathrm{DNu}) / \mathrm{U}(\mathrm{Nd}+\mathrm{Nu}) \mathrm{X} 100$}

Where: $N u$ is the number of undamaged grains; $N d$ is the number of damaged grains; $U$ is the weight of undamaged grains; and $D$ is weight of damaged grains.

Separate sieves were used to separate the grains, and the frass from each treatment was weighed and the means compared. 


\section{RESULTS AND DISCUSSION}

\section{Survey}

A summary of survey results from the three districts of the Volta Region

Respondent profile: this section covers the respondent's gender, age group, marital status, educational level, dependents, and farming experience. The study discovered that both men and women were active in utilizing plants to manage pests of stored products, albeit the demographics indicated a higher proportion of female respondents $(72 \%)$. Farmers' ages and educational levels did not differ significantly across the three districts. While all respondents were adults, $60 \%$ were between the ages of 40 $60,94 \%$ of farmers had some level of schooling, and $85 \%$ were married with dependents (Table 2). At least $70 \%$ of respondents reported had 10-20 years of expertise growing and utilizing botanicals to conserve their produce.

Type of crops grown and storage method by farmers in Volta Region

Although a variety of crops were planted, $90 \%$ of respondents cultivated maize for subsistence farming, primarily during the minor season for storing. Farmers harvest and store their crops manually in the majority of cases. For example, $50 \%$ of farmers stored their corn in cribs, while the other half stored grains in $15 \mathrm{~L}$ oil gallon (hermetic) containers with plant parts, barns, and sacks (Figure 1).

Table 2. A summary of survey results from the three districts of the Volta Region, Ghana

\begin{tabular}{lcc}
\hline & Frequency & Percentage \\
\hline Sex & 25 & 28 \\
Male & 65 & 72 \\
Female & & \\
Age of farmers (range) & 0 & 0 \\
Under 21 & 22 & 25 \\
$21-40$ & 54 & 60 \\
$41-60$ & 14 & 15 \\
Above 60 & & \\
Educational level & 5 & 6 \\
None & 49 & 54 \\
Basic & 27 & 30 \\
Secondary & 9 & 10 \\
Tertiary & & \\
Method of storage & 45 & 50 \\
Crib & 15 & 17 \\
Barn & 30 & 33 \\
Hermetic & 60 & 100 \\
Total & & \\
\hline
\end{tabular}
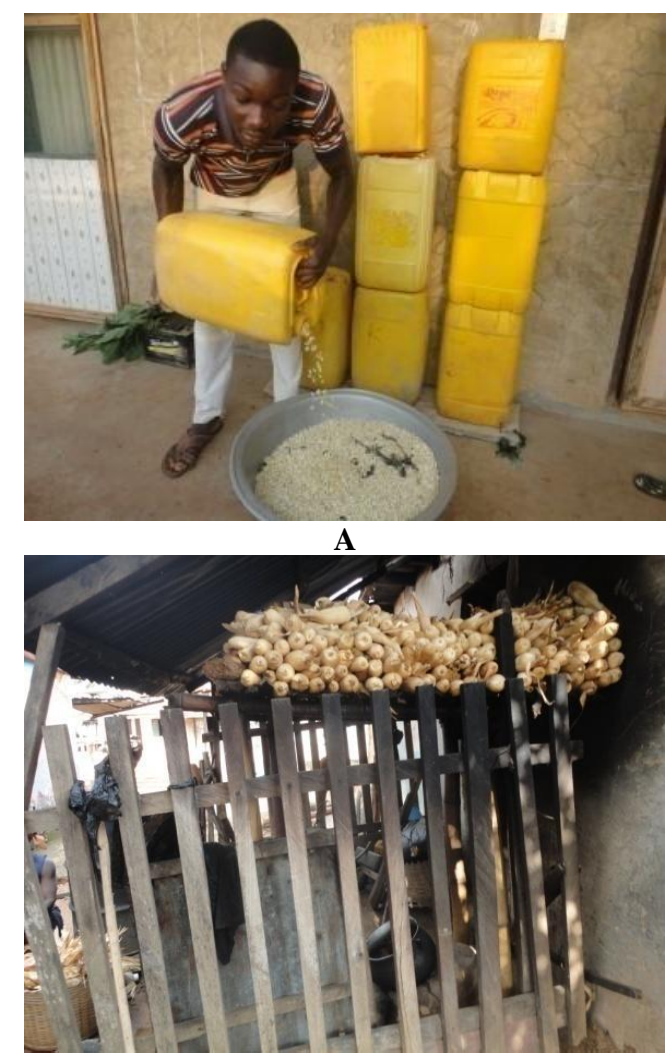

C

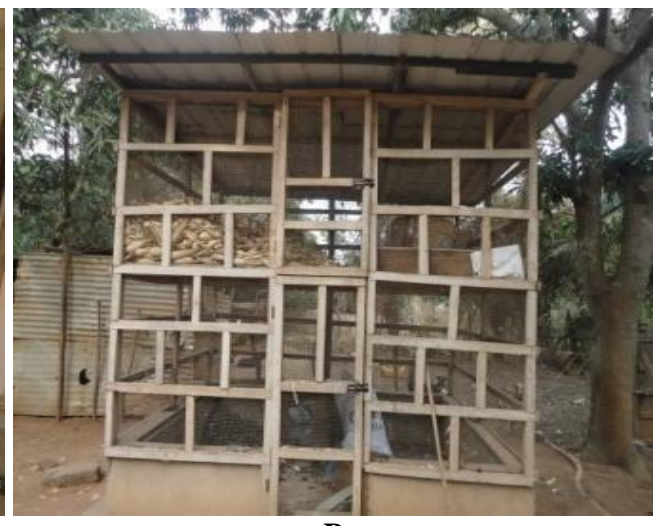

B

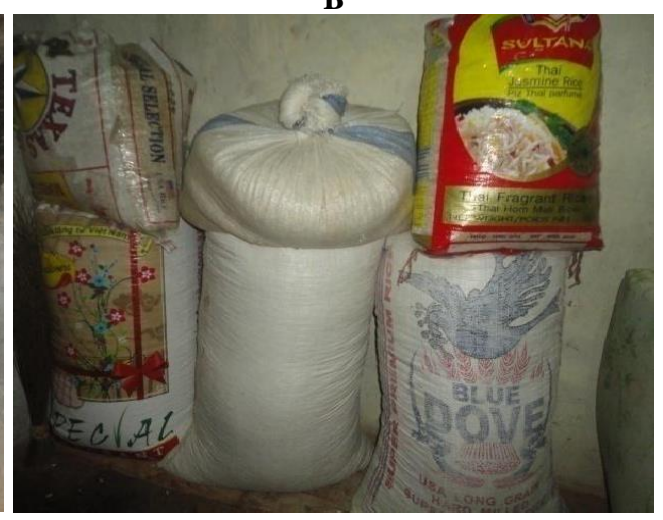

D

Figure 1. Methods of maize storage with plant parts in Jasikan, Afadjato and South Dayi Districts, Volta Region, Ghana. A. Integrated storage method, B. Crib, C. Barn, D. Integrated Storage Method 
The use of plant elements, effectiveness and marketing of grains treated with botanicals

According to the survey, $90 \%$ of respondents utilized just plant elements, while $10 \%$ used plant elements and synthetic chemicals (Actellic). Farmers utilized a total of seven plant species to prevent their wheat from insect pest infestation (Table 3 ). From $73.5 \%$ respondents agreed that A. indica, C. anisata, P. nitida, and V. amygdalina were more effective at managing stored insect pests than the other plant species. All respondents agreed that there were no issues with the sale of grains preserved with plant elements.

\section{Effect of plant powder on Sitophilus zeamais and Prostephanus truncatus in treated maize}

Figure 2 illustrates the reaction of all six plant powders at $5 \%$ and $10 \%$ against adult $P$. truncatus and S. zeamais after seven days. After seven days of treatment with all six plant powders at $5 \%$ and $10 \%, S$. zeamais survival ranged between $54-86 \%$ and $41-64 \%$, respectively, while $P$. truncatus survival ranged between $55-86 \%$ and $42-71 \%$. All of the readings were significantly ( $\mathrm{P}$ and $<0.05)$ less than what Actellic induced.

\section{Contact toxicity by topical application}

Table 4 shows the adult mortality of $P$. truncatus and $S$. zeamais after contact toxicity with methanol extracts of $C$. anisata, $P$. amarus, $P$. nitida, and $V$. amygdalina at concentrations of $0.1 \mathrm{~g} / \mathrm{mL}$ and $0.2 \mathrm{~g} / \mathrm{mL}$. The results revealed that the type of plant and the concentration of extract applied had a substantial $(\mathrm{P}<0.05)$ impact on the toxicity of methanol extracts of various plants. In the lower $(0.1 \mathrm{~g} / \mathrm{mL})$ concentration, mortality in $P$. truncatus and $S$.

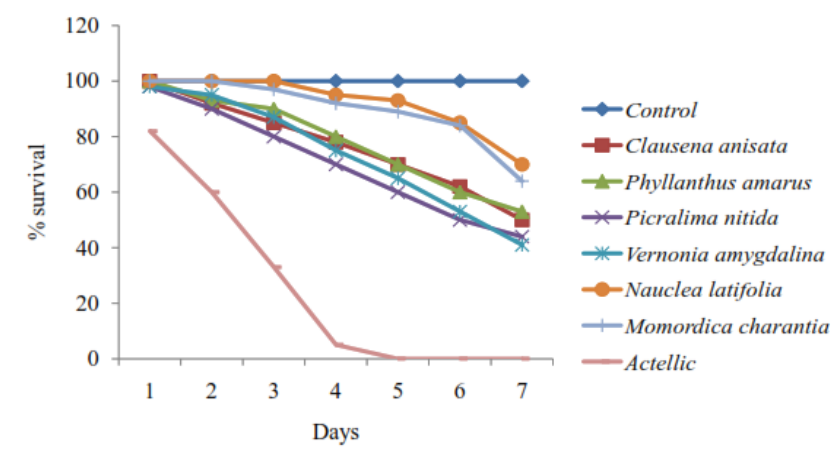

A

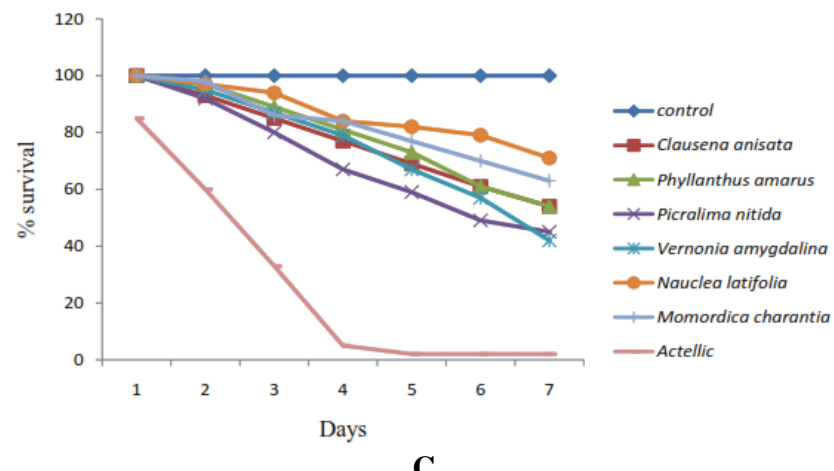

$\mathbf{C}$ zeamais was $36.7-60 \%$ and $50-70 \%$, respectively, whereas, in the higher $(0.2 / \mathrm{mL})$ concentration, mortality was 50 $83 \%$ and $56.7-86.7 \%$ in P. truncatus and S. zeamais, respectively. Insect mortality was higher in the higher concentration than in the lower concentration.

\section{Toxicity of extracts to Sitophilus zeamais and Prostephanus truncatus in treated grain.}

Figure 3 shows the effects of methanol extracts of $C$. anisata, $P$. amarus, $P$. nitida, and $V$. amygdalina at concentrations of $0.1 \mathrm{~g} / \mathrm{mL}$ and $0.2 \mathrm{~g} / \mathrm{mL}$ on adult insects in treated grains. In both treatments, the survival of both insects rose as the concentration increased. However, at 0.1 $\mathrm{g} / \mathrm{mL}, P$. truncatus and $S$. zeamais had the lowest survival rates of $35 \%$ and $38 \%$, respectively, while at $0.2 \mathrm{~g} / \mathrm{mL}$, they had even worse survival rates of $28 \%$ and $23 \%$. In almost all of the treatments, the reference product had zero survival.

Table 3. Botanicals used by farmers in Volta Region, Ghana to store maize grains.

\begin{tabular}{lll}
\hline Botanicals & Local name & Common name \\
\hline Azadirachta indica & Liliti & Neem \\
Clausena anisata & Ayira & Horsewood \\
Phyllanthus amarus & Kpavideme & Phyllantus \\
Picralima nitida & Quinine & Akuamma plant \\
Vernonia amygdalina & Gboti & Bitter Leaf \\
Nauclea latifolia & Nyimske & African peach \\
Momordica charantia & Kakle & Bitter gourd \\
\hline
\end{tabular}

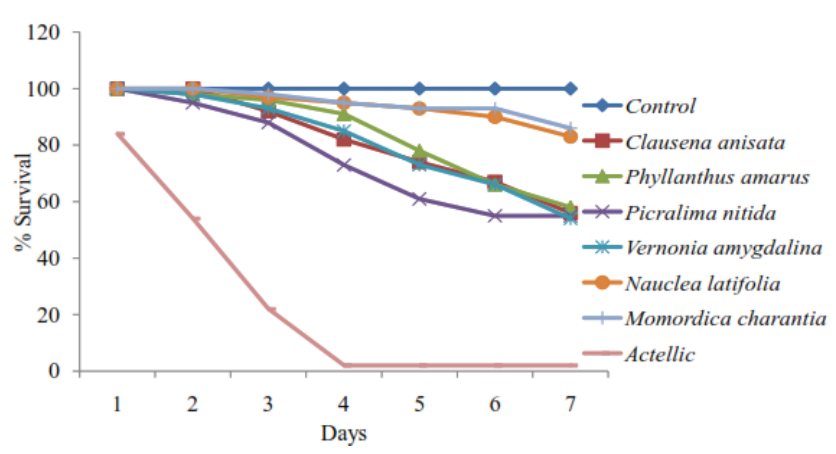

B

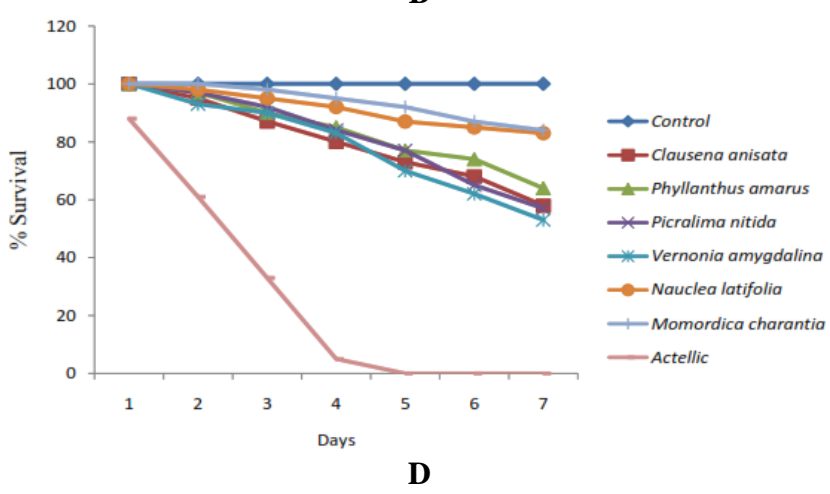

Figure 2. Effect of the powders of six plant species at: A. $10 \%$ on the survival of adult Sitophilus zeamais, B. 5\% on the survival of adult S. zeamais, C. $10 \%$ on the survival of adult Prostephanus truncatus. D. $5 \%$ on the survival of adult $P$. truncatus 


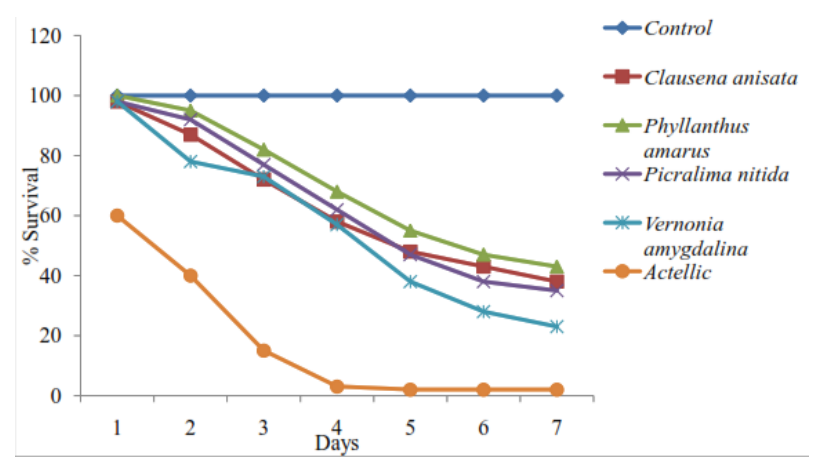

$\mathbf{A}$

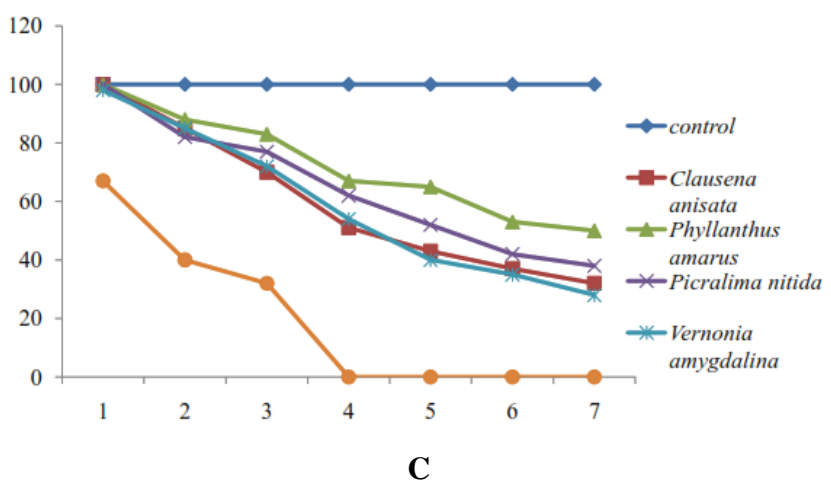

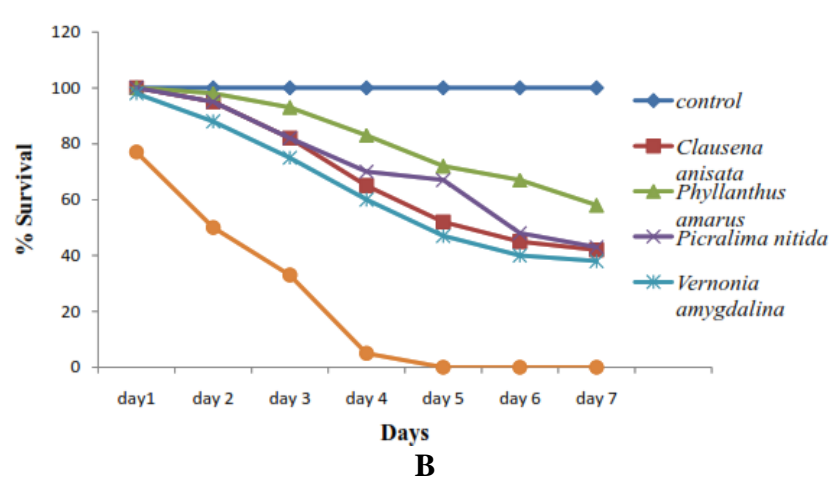

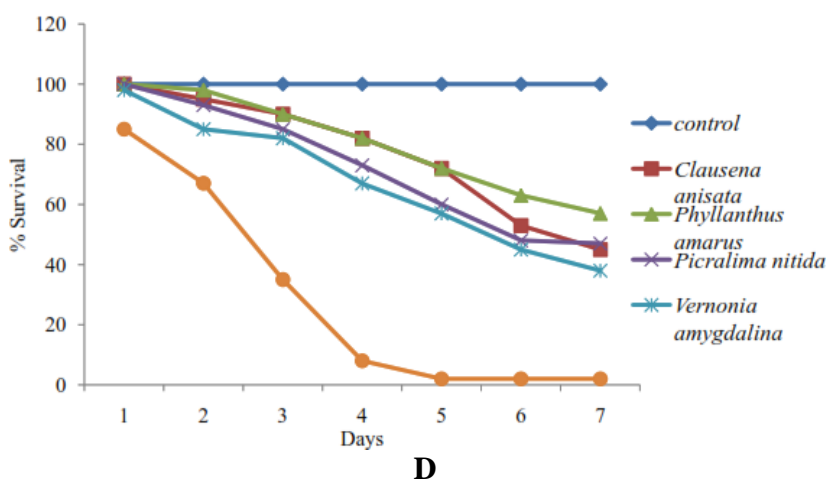

Figure 3. Effect of methanol extract of four plant species at: A. $0.2 \mathrm{~g} / \mathrm{mL}$ on the survival of adult Sitophilus zeamais in treated grain, B. $0.1 \mathrm{~g} / \mathrm{mL}$ on the survival of adult $S$. zeamais in treated grain, C. $0.2 \mathrm{~g} / \mathrm{mL}$ on the survival of adult Prostephanus truncatus in treated grain, D. $0.1 \mathrm{~g} / \mathrm{mL}$ on the mortality of adult $P$. truncatus in treated grain

\section{Effect of methanol extract of plants on oviposition of} Prostephanus truncatus and Sitophilus zeamais

In Figure 4, the number of eggs laid by $P$. truncatus and $S$. zeamais on grains $(50 \mathrm{~g})$ treated with $C$. anisata, $P$. amarus, $P$. nitida, $V$. amygdalina at concentrations of 0.1 $\mathrm{g} / \mathrm{mL}$ and $0.2 \mathrm{~g} / \mathrm{mL}$, and Actellic $(2 \mathrm{~mL} / \mathrm{L})$ are shown. When compared to the lower concentration, the higher concentration had the fewest eggs (3.0 and 4.0) laid by $P$. truncatus and $S$. zeamais, respectively (4.5 and 5.3). The difference between the eggs placed on the treated grains and the control was significant $(\mathrm{P}<0.5)$. The reference product (Actellic) was found to be more effective than other treatments in reducing the quantity of eggs laid on grains.

\section{Effect of methanol extract of four botanicals on eggs and immature stages}

Effect of methanol extracts of four botanicals on eggs of Prostephanus truncatus and Sitophilus zeamais

The emergence of $P$. truncatus and $S$. zeamais in treated grain was reduced by methanol extracts of $C$. anisata, $P$. amarus, $P$. nitida, and $V$. amygdalina $(0.1 \mathrm{~g} / \mathrm{mL}$ and 0.2 $\mathrm{g} / \mathrm{mL}$ ) (Table 5). The difference between the extract-treated grains and the control grains was significant $(\mathrm{P}<0.05)$. Insects did not emerge from grains treated with Actellic, $C$. anisata, or $V$. amygdalina at a higher concentration $(0.2 \mathrm{~g} / \mathrm{L})$.

\section{Effect of methanol extract of four botanicals on the larvae} of Prostephanus truncatus and Sitophilus zeamais

The effect of leaf extracts from $C$. anisata, P. amarus, $P$. nitida, $V$. amygdalina, and Actellic on grains containing
P. truncatus and S. zeamais larvae was shown in Table 6 . There was a significant difference $(\mathrm{P}<0.05)$ between the emergence of insects in grains treated with extract and the control at both concentrations. Insect emergence was lowest at the highest concentration $(0.2 \mathrm{~g} / \mathrm{mL})$, and in some cases none at all.

\section{Effect of methanol extract of four plants on the pupae}

Prostephanus truncatus and Sitophilus zeamais

When grains were treated with plants, the extracts of $C$. anisata, $P$. amarus, $P$. nitida, and $V$. amygdalina were considerably $(\mathrm{P}<0.05)$ harmful to pupae of $P$. truncatus and $S$. zeamais when compared to the control (Table 7). At both concentrations, there was no significant $(\mathrm{P}<0.05)$ difference between botanicals and Actellic. The botanical extracts with the highest concentration $(0.2 \mathrm{~g} / \mathrm{mL})$ had the lowest survival on both insects and no pupae survival after 35 days of storage in $V$. amygdalina and C. anisata.

\section{Repellency}

Table 8 illustrates the repellent activity of $C$. anisata, $P$. amarus, $P$. nitida, and $V$. amygdalina against $P$. truncatus and $S$. zeamais in stored maize grains at concentrations of $0.1 \mathrm{~g} / \mathrm{mL}$ and $0.2 \mathrm{~g} / \mathrm{mL}$. Compared to Actellic, all plant extracts were more repellant to $P$. truncatus and $S$. zeamais. However, $P$. truncatus was more resistant to the plant extracts than $S$. zeamais in general. Furthermore, all treatments had a greater repellent effect on both insects at higher concentrations $(0.2 \mathrm{~g} / \mathrm{mL})$ than at lower concentrations $(0.1 \mathrm{~g} / \mathrm{mL})$. 


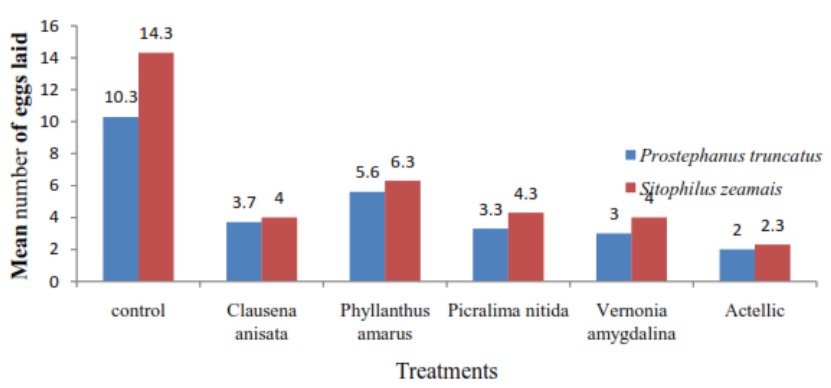

A

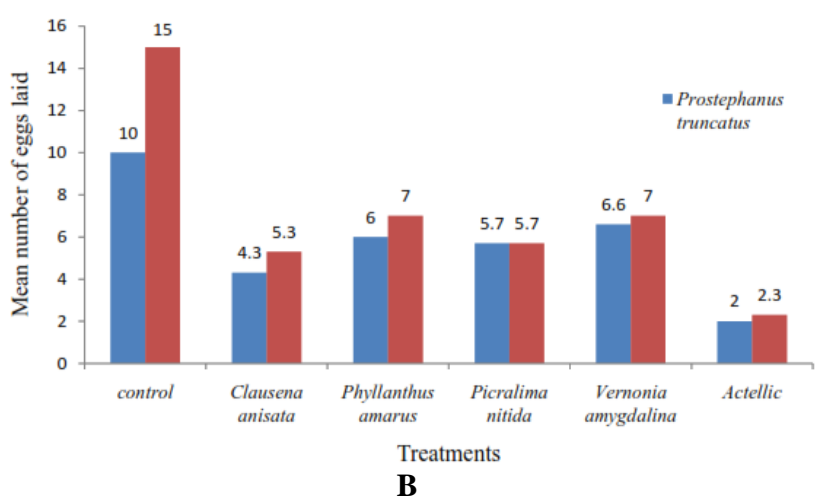

Figure 4. Effect of methanol extract of four plant species at: A. $0.2 \mathrm{~g} / \mathrm{mL}$ and B. $0.1 \mathrm{~g} / \mathrm{mL}$ on oviposition Postephanus truncatus and Sitophilus zeamais

Table 4. Contact toxicity of methanol extract of four plant species by topical application to Sitophilus zeamais and Prostephanus truncatus after $96 \mathrm{hrs}$

\begin{tabular}{|c|c|c|}
\hline \multirow[t]{2}{*}{ Treatment } & \multicolumn{2}{|c|}{$\begin{array}{c}\text { Percentage mean mortality }( \pm \mathrm{SE}) \\
\text { after } 96 \mathrm{hrs}\end{array}$} \\
\hline & P. truncatus & S. zeamais \\
\hline \multicolumn{3}{|l|}{$0.1 \mathrm{~g} / \mathrm{mL}$} \\
\hline Clausena anisata & $53.3 \pm 0.67$ & $63.3 \pm 0.67$ \\
\hline Phyllanthus amarus & $36.7 \pm 0.33$ & $50.0 \pm 0.57$ \\
\hline Picralima nitida & $50.0 \pm 1.00$ & $56.7 \pm 1.20$ \\
\hline Vernonia amygdalina & $60.0 \pm 0.58$ & $70.0 \pm 0.16$ \\
\hline Actellic & $100 \pm 0.00$ & $100 \pm 0.00$ \\
\hline Control & $00.0 \pm 0.00$ & $00.0 \pm 0.00$ \\
\hline $\operatorname{LSD}(\mathrm{P}<0.05)$ & 19.66 & 19.66 \\
\hline \multicolumn{3}{|l|}{$0.2 \mathrm{~g} / \mathrm{mL}$} \\
\hline Clausena anisata & $70.0 \pm 1.16$ & $80.0 \pm 1.16$ \\
\hline Phyllanthus amarus & $50.0 \pm 0.16$ & $56.7 \pm 1.20$ \\
\hline Picralima nitida & $73.3 \pm 1.90$ & $73.3 \pm 1.80$ \\
\hline Veroniaamydalima & $83.3 \pm 0.89$ & $86.7 \pm 0.33$ \\
\hline Actellic & $96.7 \pm 0.33$ & $100 \pm 0.00$ \\
\hline Control & $00.0 \pm 0.00$ & $00.0 \pm 0.00$ \\
\hline $\mathrm{LSD}(\mathrm{P}<0.05)$ & 20.64 & 20.6 \\
\hline
\end{tabular}

Table 5. Effect of methanol extract of four plant species on eggs of Prostephanus truncatus and Sitophilus zeamais

\begin{tabular}{lll}
\hline \multirow{2}{*}{ Treatment } & \multicolumn{2}{c}{$\begin{array}{c}\text { Mean number of adults emerged } \\
( \pm \text { SE) }\end{array}$} \\
\cline { 2 - 3 } & \multicolumn{1}{c}{ P. truncatus } & \multicolumn{1}{c}{ S. zeamais } \\
\hline $\mathbf{0 . 1} \mathbf{~ g / m L}$ & & \\
Clausena anisata & $2.0 \pm 0.33$ & $2.0 \pm 0.00$ \\
Phyllanthus amarus & $3.0 \pm 0.33$ & $2.0 \pm 0.33$ \\
Picralima nitida & $2.0 \pm 0.00$ & $1.0 \pm 0.33$ \\
Vernonia amygdalina & $1.0 \pm 0.33$ & $0.0 \pm 0.00$ \\
Actellic & $0.0 \pm 0.00$ & $0.0 \pm 0.00$ \\
Control & $8.0 \pm 1.15$ & $5.0 \pm 0.33$ \\
LSD(P<0.05) & 1.22 & 1.22 \\
$\mathbf{0 . 2}$ g/mL & & \\
Clausena anisata & $0.0 \pm 0.00$ & $0.0 \pm 0.00$ \\
Phyllanthus amarus & $1.0 \pm 1.16$ & $1.0 \pm 0.33$ \\
Picralima nitida & $1.0 \pm 0.58$ & $1.0 \pm 0.33$ \\
Vernonia amydalina & $0.0 \pm 0.00$ & $0.0 \pm 0.00$ \\
Actellic & $0.0 \pm 0.00$ & $0.0 \pm 0.00$ \\
Control & $7.0 \pm 1.15$ & $8.0 \pm 0.33$ \\
LSD(P<0.05) & 1.12 & 1.12 \\
\hline
\end{tabular}

Table 6. Effect of methanol extract of four plant species on the larvae of Prostephanus truncatus and Sitophilus zeamais

\begin{tabular}{llc}
\hline \multirow{1}{*}{ Treatment } & \multicolumn{2}{c}{$\begin{array}{c}\text { Mean number of adults } \\
\text { that emerged }( \pm \text { SE) }\end{array}$} \\
\cline { 2 - 3 } & \multicolumn{2}{c}{ P. truncatus zeamais } \\
\hline $\mathbf{0 . 1} \mathbf{~ g / m L}$ & & \\
Clausena anisata & $2.00 \pm 0.89$ & $1.00 \pm 0.33$ \\
Phyllanthus amarus & $2.00 \pm 1.20$ & $2.00 \pm 0.88$ \\
Picralima nitida & $1.00 \pm 0.88$ & $2.00 \pm 0.58$ \\
Vernonia amygdalina & $1.00 \pm 0.33$ & $0.00 \pm 0.33$ \\
Actellic & $0.00 \pm 0.00$ & $0.00 \pm 0.00$ \\
Control & $6.00 \pm 0.89$ & $4.00 \pm 0.33$ \\
LSD(P<0.05) & 1.12 & 1.12 \\
$\mathbf{0 . 2}$ g/mL & & \\
Clausena anisata & $0.00 \pm 0.00$ & $0.00 \pm 0.00$ \\
Phyllanthus amarus & $1.00 \pm 0.66$ & $1.00 \pm 0.33$ \\
Picralima nitida & $1.00 \pm 1.33$ & $1.00 \pm 0.00$ \\
Vernonia amydalina & $0.00 \pm 0.00$ & $0.00 \pm 0.00$ \\
Actellic & $0.00 \pm 0.00$ & $0.00 \pm 0.00$ \\
Control & $6.00 \pm 1.20$ & $4.00 \pm 0.88$ \\
LSD(P<0.05) & 1.61 & 1.61 \\
\hline & &
\end{tabular}

Table 7. Effect of methanol extracts of four plant species on pupae of Prostephanus truncatus and Sitophilus zeamais

\begin{tabular}{|c|c|c|}
\hline \multirow{2}{*}{ Treatment } & \multicolumn{2}{|c|}{$\begin{array}{l}\text { Percentage mean mortality } \\
( \pm \text { SE) after } 96 \mathrm{hrs}\end{array}$} \\
\hline & P. truncatus & S. zeamais \\
\hline \multicolumn{3}{|l|}{$0.1 \mathrm{~g} / \mathrm{mL}$} \\
\hline Clausena anisata & $1.00 \pm 0.00$ & $1.00 \pm 0.33$ \\
\hline Phyllanthus amarus & $2.00 \pm 0.00$ & $1.00 \pm 0.67$ \\
\hline Picralima nitida & $1.00 \pm 0.58$ & $1.00 \pm 0.66$ \\
\hline Vernonia amygdalina & $0.00 \pm 0.00$ & $0.00 \pm 0.00$ \\
\hline Actellic & $0.00 \pm 0.00$ & $0.00 \pm 0.00$ \\
\hline Control & $7.00 \pm 0.88$ & $6.00 \pm 0.33$ \\
\hline $\mathrm{LSD}(\mathrm{P}<0.05)$ & 1.46 & 1.46 \\
\hline \multicolumn{3}{|l|}{$0.2 \mathrm{~g} / \mathrm{mL}$} \\
\hline Clausena anisata & $0.00 \pm 0.33$ & $0.00 \pm 0.00$ \\
\hline Phyllanthus amarus & $2.00 \pm 0.33$ & $2.00 \pm 0.33$ \\
\hline Picralima nitida & $1.00 \pm 0.66$ & $1.00 \pm 0.33$ \\
\hline Vernonia amygdalina & $0.00 \pm 0.00$ & $0.00 \pm 0.00$ \\
\hline Actellic & $0.00 \pm 0.00$ & $0.00 \pm 0.00$ \\
\hline Control & $6.00 \pm 0.88$ & $6.00 \pm 0.60$ \\
\hline $\operatorname{LSD}(\mathrm{P}<0.05)$ & 1.22 & 1.22 \\
\hline
\end{tabular}


Table 8. Percentage mean repellency of methanol extract of four plant species on Prostephanus truncatus and Sitophilu zeamais

\begin{tabular}{lll}
\hline \multirow{2}{*}{ Treatment } & \multicolumn{2}{c}{$\begin{array}{c}\text { Percentage mean repellency } \\
\text { (PR) } \pm \text { SE }\end{array}$} \\
\cline { 2 - 3 } & \multicolumn{1}{c}{ P. truncatus } & \multicolumn{1}{c}{ S. zeamais } \\
\hline $\mathbf{0 . 1}$ g/mL & & \\
Clausena anisata & $60.0 \pm 1.56$ & $53.3 \pm 1.33$ \\
Phyllanthus amarus & $33.3 \pm 0.65$ & $26.7 \pm 0.65$ \\
Picralima nitida & $46.7 \pm 1.76$ & $40.0 \pm 1.55$ \\
Vernonia amygdalina & $53.3 \pm 1.33$ & $46.7 \pm 1.76$ \\
Actellic & $33.3 \pm 1.33$ & $6.7 \pm 0.67$ \\
LSD $(\mathrm{P}<0.05)$ & 20.63 & 20.63 \\
$\mathbf{0 . 2}$ g/mL & & $66.7 \pm 2.40$ \\
Clausena anisata & $80.0 \pm 1.56$ & $46.7 \pm 1.76$ \\
Phyllanthus amarus & $53.3 \pm 0.67$ & $46.7 \pm 0.67$ \\
Picralima nitida & $60.0 \pm 1.56$ & $66.7 \pm 1.76$ \\
Vernonia amygdalina & $73.3 \pm 0.56$ & $26.7 \pm 0.67$ \\
Actellic & $33.3 \pm 1.33$ & 20.63 \\
LSD $(\mathrm{P}<0.05)$ & 20.63 & \\
\hline
\end{tabular}

\section{Loss assessment}

When grains were treated with methanol extract of plants after 10 weeks of infestation, there was a significant $(\mathrm{P}<0.05)$ difference in the weight of powder produced by $S$. zeamais and $P$. truncatus. When applied to the grains at a $0.2 \mathrm{~g} / \mathrm{mL}$ concentration of plant extract, the least mean weight of powder was reported in V. amygdalina, with a mean value of 10.5 and $7.2 \mathrm{~g}$ in $P$. truncatus and $S$. zeamais, respectively. At a $0.1 \mathrm{~g} / \mathrm{mL}$ concentration, $P$. amarus lost the most weight (24.2 g) (Table 9). Compared to the lower concentration, the greater concentration created very little powder.

\section{Damage assessment}

In general, all grains treated with plant extracts provided better pest protection than untreated grains. However, there was no statistically significant difference $(P>0.05)$ between all four plants and Actellic (Table 10). In terms of lowering weight loss, all of the plant extracts examined were more effective at higher $(0.2 \mathrm{~g} / \mathrm{mL})$ dosages than at lower $(0.1 \mathrm{~g} / \mathrm{mL})$ dosages. Compared to $S$. zeamais, $P$. Truncatus produced higher weight loss in grains treated with botanical extracts.

\section{Damage assessment}

In general, all grains treated with botanicals provided better pest protection than untreated grains. However, there was no statistically significant difference $(\mathrm{P}>0.05)$ between all four plant extracts and Actellic (Table 10). In terms of lowering weight loss, all of the botanicals examined were more effective at higher $(0.2 \mathrm{~g} / \mathrm{mL})$ dosages than at lower $(0.1 \mathrm{~g} / \mathrm{mL})$ dosages. Compared to $S$. zeamais, P. Truncatus produced higher weight loss in grains treated with botanical extracts.
Table 9. Effect of methanol extract of four plant species on grain loss (powder) caused by Prostephanus truncatus and Sitophilus zeamais after 10 weeks of treatment

\begin{tabular}{|c|c|c|}
\hline \multirow[t]{2}{*}{ Treatment } & \multicolumn{2}{|c|}{$\begin{array}{c}\text { Percentage mean } \\
\text { weight loss }( \pm \mathrm{SE}) \text { after } 10 \text { weeks }\end{array}$} \\
\hline & P. truncatus & S. zeamais \\
\hline \multicolumn{3}{|l|}{$0.1 \mathrm{~g} / \mathrm{mL}$} \\
\hline Clausena anisata & $18.6 \pm 2.37$ & $18.0 \pm 1.60$ \\
\hline Phyllanthus amarus & $24.2 \pm 2.23$ & $22.8 \pm 1.42$ \\
\hline Picralima nitida & $14.5 \pm 1.66$ & $12.4 \pm 1.84$ \\
\hline Vernonia amygdalina & $11.5 \pm 1.53$ & $8.0 \pm 0.52$ \\
\hline Actellic & $1.4 \pm 0.06$ & $1.4 \pm 0.07$ \\
\hline Control & $30.0 \pm 0.58$ & $31.0 \pm 0.86$ \\
\hline $\operatorname{LSD}(\mathrm{P}<0.05)$ & 4.22 & 4.22 \\
\hline \multicolumn{3}{|l|}{$0.2 \mathrm{~g} / \mathrm{mL}$} \\
\hline Clausena anisata & $13.5 \pm 1.52$ & $11.9 \pm 0.54$ \\
\hline Phyllanthus amarus & $22.0 \pm 0.99$ & $23.0 \pm 1.94$ \\
\hline Picralima nitida & $13.4 \pm 0.58$ & $11.4 \pm 1.16$ \\
\hline Vernonia amydalina & $10.5 \pm 0.33$ & $7.2 \pm 0.69$ \\
\hline Actellic & $1.4 \pm 0.12$ & $1.4 \pm 0.07$ \\
\hline Control & $30.0 \pm 0.58$ & $31.0 \pm 0.86$ \\
\hline $\operatorname{LSD}(\mathrm{P}<0.05)$ & 2.75 & 2.75 \\
\hline
\end{tabular}

Table 10. Effect of methanol extract of botanicals on damage caused by Prostephanus truncatus and Sitophilus zeamais after 10 weeks of treatment

\begin{tabular}{lll}
\hline \multirow{2}{*}{ Treatment } & \multicolumn{2}{c}{$\begin{array}{c}\text { Percentage mean } \\
\text { weight loss }( \pm \text { SE) after 10 weeks }\end{array}$} \\
\cline { 2 - 3 } & \multicolumn{1}{c}{ P. truncatus } & \multicolumn{1}{c}{ S. zeamais } \\
\hline $\mathbf{0 . 1} \mathbf{~ g / m L}$ & & \\
Clausena anisata & $1.41 \pm 2.28$ & $2.1 \pm 0.14$ \\
Phyllanthus amarus & $5.28 \pm 1.32$ & $4.18 \pm 0.59$ \\
Picralima nitida & $2.60 \pm 2.25$ & $3.34 \pm 0.83$ \\
Vernonia amygdalina & $1.14 \pm 0.69$ & $0.59 \pm 0.12$ \\
Actellic & $0.69 \pm 0.27$ & $0.52 \pm 0.09$ \\
Control & $13.33 \pm 2.99$ & $11.02 \pm 4.19$ \\
LSD $(\mathrm{P}<0.05)$ & 6.46 & 6.46 \\
$\mathbf{0 . 2}$ g/mL & & \\
Clausena anisata & $0.69 \pm 0.45$ & $0.49 \pm 0.23$ \\
Phyllanthus amarus & $3.66 \pm 1.45$ & $3.47 \pm 1.19$ \\
Picralima nitida & $1.89 \pm 0.45$ & $1.88 \pm 0.60$ \\
Veronica amygdalina & $0.66 \pm 0.96$ & $0.39 \pm 0.18$ \\
Actellic & $0.32 \pm 0.23$ & $0.41 \pm 0.27$ \\
Control & $11.56 \pm 2.07$ & $9.91 \pm 1.68$ \\
LSD $(\mathrm{P}<0.05)$ & 3.64 & 3.64 \\
\hline
\end{tabular}

\section{Discussion}

Survey

The survey revealed that both men and women are involved in farming and mostly employ plants to protect stored maize grains from insect pests. However, most respondents were female, confirming previous research by Cornelius et al. (2008) indicating approximately $70 \%$ of women generated $80 \%$ of household food in Africa. Matobola (2014) also noted that while more women were engaged in rural agricultural economic sub-sectors, they lacked access to assets, limiting their ability to acquire inputs. As a result, such households were forced to rely on indigenous materials to produce and preserve crops on a big scale. 
The seven plant species used were A. indica, $V$. amygdalina, $P$. nitida, C. anisata, $P$. amarus, $N$. latifolia, and $M$. charantia, decreasing order of efficiency in pest control. A. indica was not chosen for the research since its efficacy against grain storage pests has been well known for an extended time.

\section{Effect of plant powders on Prostephanus truncatus and Sitophilus zeamais}

After seven days of treatment, the crushed powders of $C$. anisata, $P$. amarus, $P$. nitida, $V$. amygdalina, $N$. latifolia, and $M$. charantia showed varying efficiency degrees against $P$. truncatus and $S$. zeamais in treated grains. Insect survival decreased when the powder concentration increased from $5 \%$ to $10 \%$.

The survival of $P$. truncatus and $S$. zeamais in grains treated with $10 \% \mathrm{~V}$. amygdalina powder demonstrated that the plant is a promising control agent against the two insects due to its alkaloid content, which included caffeine, cocaine, morphine, and nicotine Irvine (1961). However, these chemicals are harmful to both insects and may have contributed to the insects' low survival rates in the treated grains. This finding confirms Irvine's (1961) earlier finding that the biter principle, vernonine, in $V$. amygdalina is toxic to mites. Similarly, Bouda et al. (2001) and Asawalam and Hassanali (2006) previously stated that the toxicity of $V$. amygdalina essential oil against $S$. zeamais was ascribed to the primary component terpenoids, which act as neurotoxins in insects.

The results of this study showed that $P$. nitida powder had a protective effect against two insect species that feed on stored maize grains (Ojo and Ogunleye 2013). The high lethality of the aqueous leaf and seed extract of $P$. nitida against Anopheline larvae and several kinds of fungi may be due to the presence of bioactive substances such as alkaloids, cardiac glycosides, saponins, tannins, flavonoids, terpenes, and steroids in the studied plant (Mujeeb et al. 2014). These chemicals may have contributed to the decreased survival of $P$. truncatus and $S$. zeamais in treated grains, explaining the efficacy of $P$. nitida in our investigation.

When $P$. amarus powder was administered at a $5 \%$ concentration, it was found to be effective in reducing $S$. zeamais and $P$. truncatus survival to $56 \%$. The survival rate of insects was further reduced to $52 \%$ when the powder dosage was increased to $10 \%$. Jayakumar (2010) previously demonstrated that greater concentrations of plant extracts were more efficient at reducing oviposition and increasing the death of target insect pests than lower concentrations.

Clausena anisata leaf powder's efficacy against the two insects suggested a possible contact action. This could be because the leaf oil contains the highly poisonous chemical component "estragole" (Sentilkumar and Venkatesalu 2009). The leaf powder of $C$. anisata may have contained additional chemical components that inhibited insects from eating on grains treated with the powder.

The use of $N$. latifolia and $M$. charantia powder as grain protectants against $S$. zeamais and $P$. truncatus resulted in a much greater survival rate than the other four plant species discussed previously.
While, N. latifolia and M. charantia contain alkaloids, terpenoid, morphine, and phenol, their concentrations may be lower in the plant portions utilized in the experiment than in the other four plant species (Akinkurolere 2012). This could explain why $P$. truncatus and $S$. zeamais survived so well in the treated grains. This observation contradicts Akinkurolere's (2012) conclusion that $M$. charantia is extremely poisonous to $S$. zeamais and $C$. maculatus. The difference in efficacy of these plants could also be attributed to changes in meteorological and soil variables, as well as the parts used and harvesting time (Jorge et al. 2009; Ndomo et al. 2009).

\section{Toxicity of extracts applied topically to insects}

After 96 hours of topical application, all plant extracts were harmful to insects at varying concentrations compared to the control. The greater concentration $(0.2 \mathrm{~g} / \mathrm{mL})$ was more effective against both insects than the lower concentration $(0.1 \mathrm{~g} / \mathrm{mL})$ in all treatments. Due to the presence of chemical substances such as alkaloids, flavonoids, lignans, and vernonine in $V$. amygdalina, it was very harmful to both insects (Irvine 1961). At $0.2 \mathrm{~g} / \mathrm{mL}, V$. amygdalina was 83.3 percent lethal to $P$. truncatus and $86.7 \%$ lethal to $S$. zeamais. This confirms previous studies undertaken by Asawalam and Hassanali (2006), who discovered that essential oil of $V$. amygdalina contained a variety of terpenoids and triggered 82 percent mortality in S. zeamais after 7 days of treatment with $750 \mathrm{mg} / 250 \mathrm{~g}$ of essential oil. Prostephanus truncatus was more resistant to methanol extract than $S$. zeamais, which may be explained by its more robust character, high feeding ability, and heavily sclerotized cuticle, which may have limited the active component of the extract's physical absorption through the cuticle.

Toxicity of extracts to Sitophilus zeamais and Prostephanus truncatus in treated grain

After seven days, the methanol extracts at both concentrations were applied to adult insects in treated grain, causing a substantial $(\mathrm{P}<0.05)$ reduction in survival for both insects compared to the control. The species of plant, the dose administered, and the time of contact all had an effect on the toxicity of the extract applied to adult insects in treated grain (days). Vernonia amygdalina was the most effective plant species, whereas $P$. amarus was the least effective. Although $P$. amarus includes similar chemical elements such as lignans, flavonoids, and phyllanthin, they may not have been as effective as $V$. amygdalina at killing insect pests. They can, however, be employed to prevent fungus from attacking stored grains (Oudhia 2008). The higher concentration of the herb resulted in a reduction in insect survival. Due to the continual buildup of the botanical's chemical component in the insects, the period of contact (days) had a substantial effect on the percentage survivability of adult $P$. truncatus and S. zeamais. While the standard (Actellic) caused $100 \%$ death or no survivorship after five days of contact, $V$. amygdalina at $0.2 \mathrm{~g} / \mathrm{mL}$ caused $62 \%$ mortality or $38 \%$ survival in $P$. truncatus after five days off treatment. As a result, the extracts killed insects more slowly than the 
manufactured toxin (Actellic). This finding corroborates an earlier observation by Obeng-Ofori and Dankwah (2004) that Actellic had a quick knockdown effect, instantly killing adult insects on contact.

\section{Effect of methanol extract of plants on oviposition of Prostephanus truncates and Sitophilus zeamais}

After seven days of treatment, all plant extracts successfully lowered the quantity of eggs laid by both insects compared to the control. At a $0.2 \mathrm{~g} / \mathrm{mL}$ dosage, $C$. anisata was the most efficient of all the plant extracts against both insects. This suggests that $C$. anisata may have repellant and/or oviposition deterrent properties, resulting in alterations in the adult insects' physiology and behavior, as indicated in their egg laying capacity. This supports the findings of Schmuttere (1990) and Ndomo et al. (2009) that plant extracts and essential oils reduce oviposition and fecundity in a variety of insects. Sitophilus zeamais lay more eggs than $P$. truncatus in all of the treatments. This could be due to $S$. zeamais having a higher fecundity level than $P$. truncatus.

\section{Effect of methanol extract of plants on eggs and immature stages of Prostephanus truncatus and Sitophilus zeamais}

In comparison to the control, the methanol extracts of all plants were effective against the eggs, larvae, and pupae of $P$. truncatus and $S$. zeamais at both doses. This supports the findings of Jayakumar et al. (2003), who found that plant extracts had a clear effect on postembryonic survival of the insect, resulting in a reduction in adult emergence when different plants are used. Because of the toxicity of extracts to eggs, larvae, and pupae, the number of adults emerging from treated seeds was significantly reduced. The potency could be owing to the extract's bitter antinutritive secondary metabolites acting as a barrier on the seed coat, preventing the eggs from developing into adults (Tchinda 2011). After 35 days of treatment, a $0.2 \mathrm{~g} / \mathrm{mL}$ methanol extract of $V$. amygdalina and $C$. anisata completely blocked the development of eggs, larvae, and pupae of both insects into adults. This is on par with the gold standard (Actellic), which also completely inhibited adults.

When compared to the juvenile stages developing inside cowpea seed, the eggs of $P$. truncatus and $S$. sitophilus in treated grains were more vulnerable to the extracts of $V$. amygdalina. This could be due to the extract's reduced action to pupae compared to larvae due to relative inactivity, reduced metabolism, and superior exoskeleton growth in both insects. This supports LawOgbomo and Enobakhare's (2007) findings that 1 to $5 \mathrm{~g}$ of $V$. amygdalina dry leaf powder suppressed the growth of $S$. zeamais and $S$. oryzae on stored maize grains and rice. The total prevention of the development of eggs and immature stages within the treated grain increases the ability of $V$. amygdalina and $C$. anisata to protect stored grains from insect damage.

\section{Repellency}

All four plant extracts were found to resist $P$. truncatus and $S$. zeamais better than the synthetic commercial pesticide (Actellic). C. anisata, on the other hand, was found to be very repellent to the two insects tested, with overall mean repellency of $80.0 \%$ and $66.7 \%$ for $P$. truncatus and $S$. zeamais, respectively, at $0.2 \mathrm{~g} / \mathrm{mL}$. Tchinda (2011) discovered that dried leaves of $C$. anisata were utilized as insect repellents throughout tropical Africa, and that the leaves were used as mattress filling in Kenya, because they were scented and repelled insects. Carbazole alkaloids, peptide derivatives, and phytosterol are the main chemical components of $C$. anisata, which may explain the strong insect repellent properties of the plant (Songue et al. 2012).

\section{Damaged assessment}

The greater concentration $(0.2 \mathrm{~g} / \mathrm{mL})$ of evaluated plants resulted in lower mean weight loss in the treated grains than the lower concentration $(0.1 \mathrm{~g} / \mathrm{mL})$. The number of damaged seeds in maize treated with plant extracts was significantly lower than control. Law-Ogbomo and Enobakhare (2007) concurred that the proportion of pierced grain in the treated grain with $V$. amygdalina was lower than the untreated control grain. Vernonia amygdalina is also an efficient grain protestant against $S$. zeamais, according to Enobakhare and Law-Ogbomo (2002). Sitophilus zeamais was able to inflict greater damage to grains than $P$. truncatus. Due to the high humidity in the bioassay, some of the plant extract-treated grains, excluding $V$. amygdalina, were attacked by Aspergillus flavus. According to Ogbebor et al. (2007), inhibitory activity of $V$. amygdalina is due to secondary metabolites that are resistant to fungus

In terms of plant and bug kind, the powder generated after ten weeks of storage varies. Prostephanus truncatus produced more powder than S. Sitophilus, according to the findings. This could be attributed to its hardy nature, exploratory nature, and capacity to feed and breed in dry environments, including maize with a moisture level of $9 \%$ (Cornelius et al. 2008).

In conclusion, the bioactivity of six indigenous plants in the management of $S$. zeamais and P. truncatus in stored maize was identified and analyzed in this study. Azadirachta indica, C. anisata, P. amarus, $P$. nitida, $V$. amygdalina, $N$. latifolia, and $M$. charantia were identified as plant species utilized by farmers in the Volta Region to manage insect pests in maize. Azadirachta indica, on the other hand, was not chosen because it has already undergone significant research. When applied at 5\% and $10 \%$ concentrations, the powders of the other six botanicals were poisonous to $P$. truncatus and $S$. zeamais, lowering insect survival. The botanical $V$. amygdalina was shown to be the most promising in terms of safeguarding maize grains from the two insects. Insecticides, antifeedants, antiovipositant, ovicidal, and repellent activities are all present in the methanol extract of $V$. amygdalina. After 96 hours, contact treatment of a methanol extract of $V$. amygdalina at $0.2 \mathrm{~g} / \mathrm{mL}$ eradicated $83.3 \%$ of $P$. truncatus and $86.7 \%$ of $S$. zeamais, respectively. This did not differ significantly $(\mathrm{P}<0.05)$ from the standard (Actellic). In comparison to the control, insect mortality in maize grains treated with $V$. amygdalina methanol extract was extremely high. After 10 
weeks, insect damage to maize grains treated with $V$. amygdalina in a crib was minor, and it did not differ much from Actellic. Both insects laid a few eggs in maize grains treated with $C$. anisata extract. When grains were treated with extract of $V$. amygdalina and the standard, adult emergence from eggs, larvae, and pupa was completely inhibited (Actellic). The repellency of $C$. anisata extract $(0.2 \mathrm{~g} / \mathrm{mL})$ to insects was significantly significant in comparison to the standard. The presence of toxicants and growth inhibitors in $V$. amygdalina when applied to $P$. truncatus and $S$. zeamais suggests that they have a lot of promise for storage pest management, particularly in farm stored grains of peasant farmers. The investigation also confirmed the scientific reality that farmers utilize $V$. amygdalina as a grain protectant.

\section{REFERENCES}

Akinkurolere RO. 2012. Comparative effects of three plant powders and pirimiphos-methyl against the infestation of Callosobruchus Maculatus (F.) (Coleoptera: Bruchidae) in cowpea seeds. SOAJ Entomol Stud 1 (2): 108-117.

Asawalam EF, Hassanali A. 2006. Constituents of the essential oil of Vernonia amygdalina asmaize weevil protectants. Trop Subtrop Agroecosyst 6 (2): 95-102.

Bouda H, Tapondjo A, Fotem DA, Gumedzoe MYD. 2001. Effect of essential oils from leaves of Ageratum conyzoides, Lantana Camara and Chromolaena odorata on the mortality of Sitophilus zeamais (Coleoptera, Curculionidae). J Stored Prod Res 37 (2): 103-109. DOI: 10.1016/s0022-474x(00)00011-4.

Boxall RA. 2001. Damage and loss caused by the larger grain borer Prostephanus truncatus. J Integr Pest Manag 7 (2): 105-121. DOI: 10.1023/A:1026397115946.

Cornelius EW, Bani RJ, Boateng BA Egyir IS Josaih MN, Obeng-Ofori D, Ofosu-Anim J, Timpo SE. 2008. Postharvest Science and Technology. Smartline Ltd, University of Ghana, Legon.

Elhag EA. 2000. Deterrent effects of some botanical products on oviposition of the cowpea bruchid, Callosobruchus maculatus (F.) (Coleoptera: Bruchidae). Intl J Pest Manag 46 (2):109-113. DOI: 10.1080/096708700227462.

Enobakhare DA, Law-Ogbomo KE. 2002. Efficacy of leaf powders Ocimum gratissimum and Vernonia amygdalina as grain protectants against Sitophilus zeamais Mots. In three varieties of maize. J Agric Fish 33: 22-27.

Food and Agriculture Organization of the United Nations (FAO). 2008 Household Metal Silos: Key Allies in FAO's Fight Against Hunger. Agricultural and Food Engineering Technologies Service, Rome, Italy.

Ghanadistricts.com. 2013. Ghana Districts: A repository of all Local Assemblies in Ghana. https://www.ghanadistricts.com/

Gill HK, Garg H. 2014. Pesticides: environmental impacts and management strategies. In: Pesticides: Toxic Aspects, Larramendy ML, Soloneski S(eds.). IntechOpen, UK. DOI: 10.5772/57399.

International Institute of Tropical Agriculture (IITA). 2003. Growing Maize in Nigeria - Commercial Crop Production Guide Series. Ibadan, Oyo State, Nigeria

Irvine FR. 1961. Woody Plants of Ghana, Oxford Univ. Press, London.

Jayakumar M, Raja N, Ignacimuthu S. 2003. Efficacy of crude extracts of Hyptis suaveolens and Melochia corchorifolia on pulse beetle Callosobruchus maculates. In: Ignacimuthu S, Jeyaraj S (eds.). Biological control of Insect Pests. Phoenix Publ. House, New Delhi.

Jayakumar M. 2010. Oviposition deterrent and adult emergence activities of some plant aqueous extracts against Callosobruchus maculatus F. (Coleoptera: Bruchidae). J Biopesticides 3: 325-329.

Jorge TCM, Lenartovicz V, Andrade MW, Bonafin T, Giordani MA, Bueno NBC, Schneider DSLG. 2009. Pediculicidal activity of hydroethanolic extracts of Ruta graveolens, Melia azedarach and Sambucus australis. Lat Am J Pharm 28 (3): 457-459.

Law-Ogbomo KE, Enobakhare DA. 2007. The use of leaf powders of Ocimum gratissimum and Vernonia amygdalina for the management of Sitophilus oryzae (Lin.) in Stored Rice. J Entomol 4: 253-257. DOI: 10.3923/je.2007.253.257.

Ministry of Food and Agriculture (MOFA). 2008. Production of Major Crops in Ghana. Policy, Planning, Monitoring and Evaluation Division, Accra, Ghana.

Mujeeb F, Bajpai P, Pathak N. 2014. Phytochemical evaluation, antimicrobial activity, and determination of bioactive components from leaves of Aegle marmelos. Biomed Res Int 2014: 497606. DOI: $10.1155 / 2014 / 497606$.

Ndomo AF, Tapondjou AL, Tendonkeng F, Tchouanguep FM. 2009. Evaluation des propriétés insecticides des feuilles de Callistemon viminalis (Myrtaceae) contre les adultes d'Acanthoscelis obtectus (Say) (Coleoptera: Bruchidae). Tropicultura 27 (3): 137-143.

Obeng-Ofori D, Dankwah JA. 2004. Comparative efficacies of three insecticidal materials and steam treatment for protection of Bambara groundnut against Callosobruchus maculates (Fab.) (Coleoptera: Bruchidae). Ghana J Agric Sci 37: 33-42. DOI: 10.4314/gjas.v37i1.2077.

Obeng-Ofori D, Reichmuth CH. 1997. Bioactivity of Eugenol a major component of essential oils of Ocimum suave (Wild) against four species of stored product Coleoptera. Int J Pest Manag 43 (1): 89-94. DOI: 10.1080/096708797229040.

Obeng-Ofori D. 2007. The use of botanicals by resource poor farmers in Africa and Asia for the protection of stored agric products. Stewart Postharvest Rev 6 (5): 1-18. DOI:10.2212/spr.2007.6.10.

Ogbebor NO, Adekunle AT, Enobakhare DA. 2007. Inhibition of Colletotrichum gloeosporioides (Penz) Sac. causal organism of rubber (Hevea brasiliensis Muell. Arg.) leaf spot using plant extracts. Afr J Biotechnol 6: 213-218.

Ojo DO, Ogunleye RF. 2013. Comparative Effectiveness of the Powders of Some Underutilized Botanicals for the Control of SitophilusZeamais (Motschulsky) (Coleoptera: Curculionidae ) Ekiti State University, Ado-Ekiti, Nigeria.

Osafo WF. 1998. Extracts of Three Plant Materials as Post-Harvest Grain Protectants Against Sitophilus zeamais (Most) (Coleoptera: Curculionidae), University of Ghana, Legon.

Oudhia P. 2008. Phyllanthus amarus. In: Schmelzer GH, Gurib-Fakim A. (eds.). Prota 11(1): Medicinal Plants/Plantes médicinales [CD-Rom]. PROTA, Wageningen, Netherlands.

Owusu-Sekyere JD, Alhassan M, Nyarko BK. 2011. Assessment of climate shift and crop yields in the cape coast area in the Central Region of Ghana. ARPN J Agric Biol Sci 6 (2): 49-54.

Quandzie E. 2011. Ghana records $\$ 1.7$ billion trade deficit last nine months in 2011. www.ghanabusinessnews.com

Saxena RC, Jilani G, Abdul KA. 1989. Effects of neem on stored grain insects. In: Jacobson M (eds.). Focus on Phytochemical Pesticides Vol. 1 the Neem Three. CRC Press Boca Raton FL, Boca Raton, Florida.

Schmutterer H. 1990. Properties and potential of natural pesticides from the neem tree, Azadirachta indica. Ann Rev Entomol 35: 271-297. DOI: 10.1146/annurev.en.35.010190.001415.

Sentilkumar A, Venkatesalu V. 2009. Phytochemical analysis and antibacterial activity of the essential oils of Clausena anisata (Willd.) Hook.f. ex Benth. Intl J Integr Biol 5 (2): 115-120.

Songue JL, Dongo KE, Ngando MT, White RL. 2012. Chemical constituents from stem bark and roots of Clausena anisata. Molecules 17 (11): 13673-13686. DOI: 10.3390/molecules171113673.

Talukder FA, Howse PE. 2000. Isolation of secondary compounds from Aphanamixis polystachya as feeding deterrents against adult Tribolium castaneum (Coleoptera: Tenebrionidae). J Plant Dis Prot 107 (5): 498-504.

Tchinda AT. 2011. Clausena anisata (Willd.)Hook.f. Ex Benth. In: Schmelzer GH, Gurib-Fakim A (eds.) Prota 11(2): Medicinal plants/PlantesMédicinales 2. PROTA, Leiden.

Udo IO, Epidi TT, Osakwe JA. 2009. Susceptibility of Sitophilus zeamais Most and Callosobruchus maculates F. to plant parts of Ricinodendron heudelottii. J Plant Prot Res 49 (4): 411-415. DOI: 10.2478/v10045-009-0065-6.

Weaver DK, Dunkel FV, Ntezurubanza L, Jackson LL, Stock DT. 1998. The efficacy of linalool, a major component of freshly-milled Ocimum canum Sim (Lamiaceae) for protection against post-harvest damage by certain stored products Coleoptera. J Stored Prod Res 27 (4): 213-220. DOI: 10.1016/0022-474X(91)90003-U. 